\title{
International Law, War and Human Rights: The Humanitarian Response against the State of Emergency
}

\begin{abstract}
By Federico Zumpani*
The interaction between human rights and humanitarian law represents a relevant question to explain the fragmentation of international law. The separate treatment of such areas of law allows to delineate different contents and application procedures, while the joint consideration is not simple, in view of the reasons for which each of the two has been created. Humanitarian law is a set of rules of conduct limited to specific pathological situation, presumably temporary. The international human rights law is the establishment of a political and legal concept of man as endowed with certain inalienable rights that constitutes an obstacle to the arbitrary use of force by States. The aim of the paper is to identify the conflicts arising from the interaction between these regulatory systems, starting from the "derogation clauses" and the "state of emergency", circumstances in which there are suspensions of human rights in the face of a public emergency, specifically the armed conflict. Moreover, it is necessary to analyze the containment of the war between the States, establishing whether humanitarian law is a possible exception to human rights, in view of armed conflict. A key objective is to determine whether humanitarian law generates a fullfledged "State of exception", on the basis of global warfare scenario, where there are situations of chronic emergency.
\end{abstract}

The Armed Conflict as Emergency in International Law: The State of Exception

The legitimacy of the instruments of exemption by the application of human rights in armed conflict is an entirely relevant matter to establish the limits granted to the States in the conduct of hostilities. Such analysis allows to identify the main contradictions within the international and European legal systems in the concept of human rights as jus cogens. In particular, it assumes great significance to define the "state of emergency", a condition in which a State, against the need to protect its survival, which is threatened by a serious

*PhD Candidate on "Human Rights: Evolution, Protection and Limits", University of Palermo, Italy. 
and exceptional danger, establishes an extraordinary legal regime, which reduces the level of protection of fundamental human rights ${ }^{1}$.

The existence of an armed conflict implies a significance about the cause of the emergency on the applicable rules, as, in such cases, the application of the law on the protection of human rights in peacetime intersects with that of the corresponding rules of humanitarian law. First at all, in the doctrine, it is possible to find a specific approach that treats war as presenting the possibility of "justifying" a widespread suspension of legality. This theory rests on a set of judgments: first, the suspension of legality is almost inevitable; second, attempting to identify, in law, the circumstances under which legality can be suspended is futile; third, attempting to do so is pernicious as well, because it undermines the important values captured in the rule-of-law tradition ${ }^{2}$.

The hypothesis of the regimes of exception occurs in relation to governments operating after the invocation of the emergency, and this term recalls the preposition stated by Carl Schmitt, that the real sovereign is the person who has the power to invoke the exception in a nation ${ }^{3}$. In this case, starting from the assumption that war represents an event completely distinct from other emergencies, such a distinction can be found in article 15 of the European Convention on Human Rights, the article 27 of the Inter-American Convention, and article 2 of Convention against torture and other cruel, inhuman and degrading treatment or punishment. ${ }^{4}$ However, this distinction is not present in article 4 of the Arab Charter on Human Rights and in article 4 of the International Covenant on Civil and Political Rights. ${ }^{5}$ It is possible to find an initial discrepancy between the Regional Conventions and the UN Charter,

\footnotetext{
${ }^{1}$ Hafner-Burton, E. - Helfer, L. - Fariss, C. (2011). "Emergency and Escape: Explaining Derogations from Human Rights Treaties". International Organization, Vol. 65, pp. 673-707.

${ }^{2}$ Tushnet, M. (2005). Emergencies and the idea of Constitutionalism. In: The Constitution in Wartime: Beyond Alarmism and Complacency. Durham: Duke University Press, 2005, pp. 3954.

${ }^{3}$ Schmitt, C. (2005). Political Theology. Four Chapters on the Concept of Sovereignty, Chicago: University of Chicago Press, p. 13.

${ }^{4}$ In particular, article 15 of European Convention on Human Rights reads "In time of war or other public emergency threatening the life of the nation any High Contracting Party may take Measures derogating from its obligations under this Convention to the extent strictly required by the exigencies of the situation, provided That Such Measures are not inconsistent with its other obligations under international law"; article 27 of Inter-American Convention on Human Rights reads "in time of war, public danger, or other emergency that threatens the independence or security of a State Party, it may take measures derogating from its obligations under the present Convention to the extent and for the period of time strictly required by the exigencies of the situation, provided That Such Measures are not inconsistent with its other obligations under international law and do not involve discrimination on the ground of race, color, sex, language, religion, or social origin"; article 2, par. 2 of Covenant against torture and other cruel, inhuman or degrading treatment or punishment reads "No exceptional circumstances whatsoever, whether a state of war or a threat or war, internal political instability or any other public emergency, may be invoked as a justification of torture". See Dinstein, Y. (2004). The Conduct of Hostilities under the Law of International Armed Conflict. Cambridge: Cambridge University Press, p. 23.

${ }^{5}$ Human Rights Committee, General Comment No. 29, States of Emergency (Article 4), U.N. Doc. CCPR/C/21/Rev.1/Add.11 (2001).
} 
which states in article 2, par. 4 the abstention of the Member States in their international relations from the use of force against the territorial integrity and political independence of any State, or in any other manner inconsistent with the purposes of the United Nations. On the basis of this wording, it is clear that the treaties with an explicit mention of war must apply to situations of war. Otherwise, States would not have to comply with any of the requirements for derogations (declaration, notification, non-discrimination, proportionality) and the derogation clauses would become superfluous. ${ }^{1}$

The application of rules ad hoc for the protection of fundamental rights, in cases of armed conflict (international humanitarian law), implies the competition of these rules with the obligations deriving from human rights treaties applicable in times of peace and war. Paradoxically, an armed conflict does not automatically satisfy the criteria a derogation should meet as there is also a qualitative measure of severity that demands that derogations are permissible 'only if and to the extent that the situation constitutes a threat to the life of the nation'.

In respect of all circumstances legitimizing the derogation clauses, it is necessary to emphasize the meaning of "war". ${ }^{2}$ In fact, compared to the time it was drafted the European Convention on Human Rights, the hypothesis of the classic "war", preceded by a formal declaration, the main instrument for States to demonstrate unequivocally the animus bellandi and clearly define the beginning of a state of war is now obsolete in practice; therefore, the term in question must be interpreted in a broader sense, considering "armed conflicts", or by deleting the reference to war, through the generic reference to a public emergency ${ }^{3}$. In addition, the most convincing solution seems to be that due to a broad interpretation of the term, as to include internal and international armed conflicts ${ }^{4}$.

The peculiarity of warfare implies that States are often not in a position to comply fully with their human rights obligations, and they may invoke necessity as a ground precluding wrongfulness under international law. From this point of view, it may become evident that the universality of human rights is significantly lessened by the need to protect public interest. ${ }^{5}$

On the grounds of this legal basis, it is possible to understand the preconditions necessary to the temporary repeal of particular human rights guaranteed: a) existence of a state of emergency; b) respect for the principle of proportionality; c) respect for the principle of non-discrimination; d) no derogation from non-derogable rights; e) Consistency of derogation measures

\footnotetext{
${ }^{1}$ Droege, C. (2007). "The interplay between international humanitarian law and international human rights law in situations of armed conflict". Israel Law Review, no. 40, pp. 310-355.

${ }^{2}$ Antonopoulos, N. (1967). La jurisprudence des organes de la Convention europèenne des droits de l'homme. Leyden: Sijthoff, p. 219.

${ }^{3}$ Mancini, M. (2009). Stato di guerra e conflitto armato nel diritto internazionale. Giappichelli: Torino, pag. 19.

${ }^{4}$ Eboli, V. (2010). La tutela dei diritti umani negli stati d'emergenza. Giuffrè: Milano, p. 31.

${ }^{5}$ Committee on Economic, Social and Cultural Rights, General Comment No. 3, The nature of States parties obligations (Art. 2, par.1), 1990, para. 10.
} 
with the State party's other obligations under international law; f) proclamation and notification. ${ }^{1}$

The relationship between armed conflict and the derogation mechanism must be analyzed starting from two formal requirements for the legitimacy of the exceptions: they must be officially proclaimed and, then, notified to the other States Party to the treaty. In this sense, a primary relevant question is whether the procedural requirements apply to armed conflict and if so, whether a State that does not comply with them will be held to the full range of human rights. The European Court of Human Rights, in some judgments concerning violence by the Russian army in Chechnya, has based its jurisdiction on Article 2 of the European Convention, enshrining the right to life, identifying between cases when "death shall not be regarded as inflicted in contravention" of this right, to cases in which the use of force proves absolutely necessary to "suppress, in a manner consistent with the law, a riot or insurrection". In this way, the Court, without even mentioning humanitarian law, could recognize the failure on the part of the army of the requirement of absolute necessity of the action of armed repression, the requirement that there must be "not only in the decision to resort to force but also in the planning and execution of action". In this way, the Strasbourg judges circumvented the limits of humanitarian law, in particular when it relates to non-international conflicts, to ensure a more effective protection of fundamental rights. ${ }^{3}$ However, State practice does not confirm this understanding with respect to international armed conflict. In such situations, States have not derogated from the European Convention.

\section{Derogation Mechanism from Human Rights in Armed Conflicts: From "Jus Ad Tumultum" to "Jus in Tumultu"}

The crystallization of a state of emergency within an armed conflict implies a specific distinction: in fact, just as international law distinguishes legal rules governing the beginning of an armed conflict (jus ad bellum) from legal rules governing the conduct of hostilities (jus in bello), it also stands out rules governing the membership of a State within a state of emergency rules that govern the conduct of a State within emergencies. In this sense, the reference is to these two bodies of law would qualify as "jus ad tumultum" and "jus in tumultu", which include the establishment of emergency in international law. Paradoxically, it seems that the international community has found it necessary to grant the States heightened limitations of human rights in the

\footnotetext{
${ }^{1}$ Kèalin, W. - Künzli, J. (2009). The Law of International Human Rights Protection. New York: Oxford University Press, pp. 144-146.

${ }^{2}$ Schreuer, C. (1982). "Derogation of Human Rights in Situations of Public Emergency: The Experience of the European Convention on Human Rights". Yale Journal of World Public Order, Vol. 9, p.113.

${ }^{3}$ European Court of Human Rights, Isayeva and others v. Russia, 57947-9/00, Judgment of 24 February 2005.

${ }^{4}$ Criddle, E. - Fox-Decent, E. (2012). "Human Rights, Emergencies, and the Rule of Law".

Human Rights Quarterly. Vol. 34, pp. 39-87
} 
context of a state of emergency, to guarantee the protection of such rights, preserving public institutions with special powers ${ }^{1}$. The justification of exceptions may lie within the terms of the legal norms about the state of emergency; if there is "war, public danger, or other emergency" threatening "the independence or security" of a State Party, then any legal and moral limit dissolves. ${ }^{2}$

As regards to the jus ad tumultum, it is possible to explain authoritatively such terminology in reference to the case law. In fact, Lawless $v$. Ireland is the most important case in which a definition of "public emergency" is expressed as "danger or crisis" that is "present or imminent, exceptional, involving the whole population and constitutes a threat to the organized life of the community". ${ }^{3}$ Moreover, The Inter-American Commission on Human Rights has accepted the European Commission's formulation of the applicable legal standards, saying that an armed conflict would not support a state of emergency unless emergency measures were of limited duration and the armed conflict compromised "the continued viability of the organized community as a whole". 4

The verification of the requirements for the existence of a state of emergency implies the adoption of specific rules for the regulation and conduct of emergency in relation to the powers exercisable by the States. In particular, in Sakik and Others v. Turkey, The European Court of Human Rights stated that by international law, executive and legislative discretionary powers exercisable by States are contained, and these powers cannot be employed beyond the temporal and geographic scope specified in the notice of derogation ${ }^{5}$. Despite the notification of the derogation represents a fundamental requirement for the regulation of the state of emergency, States must define and tailor their solutions to minimize the potential impact on human rights norms. In fact, States may suspend non-peremptory human rights only if their responsive measures would comply with the geographic and temporal scope of the derogation, as well as a "substantive conception of proportionality" that demands the use of those measures that minimally restrict the freedoms protected by the suspended treaty rights ${ }^{6}$.

Therefore, until human rights theory catches up with contemporary human rights norms and practices, the international community will continue to struggle with basic questions regarding the content of jus ad tumultum and jus in tumultu, including the conditions that would justify an emergency

\footnotetext{
${ }^{1}$ Agamben, G. (2005). State of exception. Chicago: The University of Chicago Press.

2 Ackerman, B. (2004). "The Emergency Constitution”. Yale Law Journal, 1029-1031.

${ }^{3}$ Lawless v. Ireland [Lawless Commission], 1 Eur. Ct. H.R. (ser. B) at 82, § 90 (1960-1961).

${ }^{4}$ Judicial Guarantees in States of Emergency, (Arts. 27(2), 25 and 8 of the American Convention on Human Rights), Advisory Opinion OC-9/87, October 6, 1987, Inter-Am. Ct. H.R. (Ser. A) No. 9 (1987).

${ }^{5}$ European Court of Human Rights, Sakik and Others v. Turkey, 87/1996/67/897-902, 26 November 1997. In this case, the Court considered Turkey's suspension of human rights protections in territories beyond those identified in the State's derogation notice.

${ }^{6}$ Criddle, E. - Fox-Decent, E. Supra, 50.
} 
declaration, the real scope of jus cogens, and the margin of appreciation owed by international tribunals to States that derogate from their human rights obligations.

In this sense, it is necessary to describe the "fiduciary theory", based on a principle of legality that authorizes the State to exercise public powers for and on behalf of its people, but subject to strict legal constraints that safeguard subjects' inherent dignity as free and equal beneficiaries of State action. In particular, because a State assumes the public powers associated with sovereignty, it also assumes a fiduciary obligation to establish legal order on behalf of the citizens and noncitizens subject to its powers. ${ }^{1}$

Such theory states that the State itself must refrain from adopting laws, policies, or practices that deliberately victimize or arbitrarily threaten persons subject to its power. In the doctrine, there are three specific desiderata that international norms must satisfy to qualify as human rights: firstly, under the principle of integrity, human rights must have as their object the good of the people rather than the good of the State's institutions or officials; secondly, the principle of formal moral equality requires fairness or even-handed treatment of persons subject to state power; thirdly, the principle of solicitude establishes that human rights must reflect proper solicitude toward the legitimate interests of a State's subjects ${ }^{2}$.

In connection to the treaties' right, under the fiduciary theory, derogation suspends only the treaty-based obligation to respect, protect, or fulfill specific human rights. in particular, these rights are continuously possessed by the persons, on the basis of the State-subject fiduciary relationship, and such a case releases States from their treaty obligations, permitting restrictions on human rights consistent by jus in tumultu, where the rights subject to restriction are understood to flow from the State-subject fiduciary relation rather than a treaty.

On the basis of these arguments, it occurs to analyze a relevant question: is it possible to conceive non-derogable and derogable human rights? The state of emergency would seem to establish a sui generis political and legal environment, "parallel" to the legal system of human rights, as alien to any limitation due to the consideration of human rights as jus cogens. Firstly, the fiduciary theory's relational account of human rights clarifies why nonperemptory human rights are properly characterized as "rights" while nonetheless being subject to derogation during emergencies. The derogation of human rights within the ordinary state of emergency has been substantiated in the doctrinaire debate, from the fact that these rights are abstract, timeless and inalienable possessed by all human beings only by virtue of their shared humanity ${ }^{3}$. The fiduciary theory addresses the threats that arise within emergencies by authorizing the State to impose heightened restrictions on nonperemptory human rights - including, where applicable, derogations from

\footnotetext{
${ }^{1}$ Criddle, E. - Fox-Decent, E. Supra, 54.

${ }^{2}$ Fuller, L. (1964). The morality of law. Yale: Yale University Press, p. 31.

${ }^{3}$ Donnelly, J. (1998). International Human Rights. Boulder: Westview Press, pp. 18-20; Gewirth, A. (1982). Human Rights: essays on justification and application. Chicago: The University of Chicago Press, pp. 1-2.
} 
human rights conventions - in order to restore a regime of secure and equal freedom.

On the basis of these critical comments, under the fiduciary theory, the situation where a State may not declare an emergency unless exigent circumstances frustrate the State's ability to provide secure and equal freedom through reliance on the laws, practices, or procedures that apply outside an emergency imply the manifestation of jus ad tumultum; once a State, instead, determines that this threshold has been crossed and invokes emergency powers, the State must refrain from restricting human rights any further than strictly necessary to restore the ability to guarantee secure and equal freedom, this will imply the circumstances of jus in tumultu.

In relation to the jus ad tumultum, there is a principled framework offered by the fiduciary theory, starting from the State's overarching fiduciary obligation to furnish a regime of secure and equal freedom. The necessity of a declaration of a state of emergency depends on exigent circumstances frustrating the State's ability to guarantee secure and equal freedom without temporarily employing laws, policies, or practices that would constitute a breach of fiduciary duty under other circumstances. In this sense, a potential contradiction could arise in the need to ensure equal deprivation of freedom by itself, since that would imply a coercive force that would justify the derogation process as necessary. The event of a crisis and, in this case, an armed conflict would lead to the necessary existence of three fundamental factors: the exceptionality, according to which the event should be recognized as an extraordinary and urgent; contingency, for which the application of derogation must be contextual to the emergency event; the impermanence, according to which the State abandons emergency powers immediately after the cessation of the event. However, the analysis becomes more complex when it is necessary to deal with permanent or institutionalized states of emergency, which are anathema to the fiduciary principle to support the establishment of emergency of international law, and entrenched emergencies, which may satisfy the fiduciary principle so long as they retain their conditional and temporary character.

In relation to the application context of the jus in tumultu, inside the emergency, the restriction of exercise of human rights requires, by the fiduciary theory, a reasoned public justification concerning the particular measures. Despite the justification, so the motivation, of the emergency measures applied keeps a balance between state emergency power and community, however a difference between sovereignty and security remains. In particular, in the context of jus in tumultu, the principal focus of justification falls on the principle of necessity, according to which the States may restrict human rights only to the extent "strictly required" to restore public order. ${ }^{1}$

The application of derogation clauses can be contained and monitored if the State Parties shall notify any exercise of emergency powers, but this

${ }^{1}$ Silva et al. v. Uruguay, Human Rights Committee, Communication No. 34/1978, adopted April, $8^{\text {th }} 1981$, U.N. GAOR, $12^{\text {th }}$ Sess., para. 8.3, U.N. Doc. CCPR/C/12/D/34/1978 (1981). 
assumes that this requirement exists primarily to provide benefits on a national level, and not for the international community. Traditionally, notification requirements have been understood primarily as device to facilitate international monitoring, and when States provide notice of derogation pursuant to their treaty commitments, international and regional tribunals and other States-parties are better provided to check human rights abuses. Notification of emergency proclaimed ensures that the state's authority complies with the fiduciary character indwelling in the relationship with the community: in fact, emergency proclamations must identify the circumstances constituting the public emergency, the particular rights suspended, the State's responsive measures, and the State's reasons for selecting those measures. ${ }^{1}$

Then, it should be pointed that the violations of jus ad tumultum and jus in tumultu implies the application of the principle of contestability, deriving from the principle of non-domination, and described inside the doctrinaire debate. In particular, the contestation of every State's emergency power lets to prevent any possible arbitrariness deriving from the decisions made by various arms of government. In fact, the access to the reasons supporting those decisions represents the only way to participate to the emergency action by States. Whenever States violate jus ad tumultum or jus in tumultu, persons adversely affected must have access to independent review to ensure that emergency measures have an "objective justification" in international law's emergency constitution $^{2}$.

\section{The Overlapping between Human Rights and Humanitarian Law in Derogation Mechanism}

The manifestation of emergency situations arising from an armed conflict involves the question of the relationship between human rights and humanitarian law, which has opened a wide doctrinaire debate. The simultaneous application of two legal systems may involve an overlapping of rules not perfectly coincided for the protection of self-interest. Such overlapping is more pronounced when there is, in particular, an extended application of the rules of international humanitarian law. This, in turn, depends on the kind of armed conflict arisen: in fact, if it gets international armed conflicts, there will be a more complex regulatory system of protection, while, in the case of non-international armed conflicts, the regulatory system is reduced, varying in descending order according to the greater or lesser intensity of the armed conflict, which could reach the threshold for the applicability of the Second Additional Protocol or the art. 3 Common to the Geneva Conventions. As regards to international armed conflicts, the International Court of Justice stated three specific propositions about the relationship

\footnotetext{
${ }^{1}$ Report on the Situation of Human Rights in the Republic of Bolivia, Inter-American Court of Human Rights, O.A.S. Doc. OEA/Ser.L/V/II.53, doc. 6, rev. 2, ch. I, § G, II 2 (1981).

${ }^{2}$ Pettit, P. (2001). "Deliberative Democracy and the Discursive Dilemma". Philosophical Issues, Vol. 11, No. 1, 268-299.
} 
between two bodies of rules emerging from specific pronouncements: first, during an armed conflict, it remains possible to implement human rights law; second, human rights law, applicable in conditions of conflict, is subject only to derogation; third, the hypothesis of a possible simultaneous application of the two bodies of law implies the predominance of international humanitarian law as lex specialis. ${ }^{1}$

Starting from the distinctions between humanitarian law and the derogation regime of international human rights law, there are multiple situations in which high-intensity emergencies are almost indistinguishable from low-intensity armed conflicts. Such particular practice raises the important question of what law actually applies to these situations, that is, which legal regime applies within a broader accommodation model. Furthermore, it also questions the appropriateness of framing the discourse in terms of mutually exclusive categories. Although analysis of this relationship in the concrete context of "high-intensity" emergencies provides certain important insights that are relevant to these more general issues. Even if the international human rights system applies in times of peace, it is possible to underline that these norms continue to apply throughout the period of any armed conflict. States resorted to war in order to protect and defend their legal rights or to increase the State's power and possessions irrespective of its legal rights, as well as to challenge existing rights under international law ${ }^{2}$. The applicability of the two legal systems differs according to the circumstances of reference, even if the principles underlying them include the same aim to protect, making reconciliation a need for more extensive protection.

In relation to the internal armed conflicts, the persistent internal conflict is a key aspect of distinguishing high-intensity emergencies from other exigencies. In particular, the control of the State itself is disputed to some extent; the legitimacy of such disputes, namely the interference with the State's authority, is a contested issue for State's sovereignty. Such forms of internal political violence are generally branded as forms of terrorism, and any political legitimacy that might accrue to non-state actors is stripped away.

Furthermore, a secondary issue directly related to the previous one concerns the applicability of humanitarian law to situations other than armed conflict, in the absence of specific treaty obligations in this regard, and in the absence of a State practice, which often are also opposed to the application of humanitarian law in armed conflict tout court. The state of emergency non descended from armed conflict are often characterized by the use of means and methods of warfare similar to those used in military operations, so the applicability of rules relating to the conduct of (almost) hostility would be

\footnotetext{
${ }^{1}$ Chetail, V. (2003). "The Contribution of the International Court of Justice to International Humanitarian Law". International Review of the Red Cross, Vol. 85, No. 850, pp. 235-269; Zyberi, G. (2011). "The International Court of Justice and applied forms of reparation for international human rights and humanitarian law violations". Utrecht Law Review, Vol. 7, No. 1, pp. 204-215.

${ }^{2}$ Hall, W. (1924). A Treatise on International Law. Oxford: Clarendon Press, 8th edn., p. 82, cited in: Gross O. - Ní Aoláin, F. Supra, p. 329.
} 
particularly appropriate. In addition, the applicability of humanitarian law has risen a doctrinaire debate in favor of applying the regulatory system, which would favor a strengthening of the protection of individuals, because these rules are addressed to all parties to the conflict, as opposed to rights human, addressed only to the States. However, this last requirement is particularly incisive, because the States are responsible for everything that happens within their jurisdiction.

\section{Conclusions: State of Emergency as State of Exception}

The concept of the state of emergency as necessary remedy to extraordinary situations of necessity and urgency, in particular the war, represents a risk to the very existence of human rights law. In particular, this consideration may be inferred due to the fact that the application of a derogation from human rights justifies not so much the application of a specific extraordinary rule, but a parallel legal system, due to a "non-application" of legal rules. This system provides an omission in applying the human rights law, as the fundamental rule becomes the guarantee of the survival of the nation, by making any further principle to that fundamental rule. Therefore, the state of emergency manifests itself as the prelude to a state of exception, but the same exceptionality provides for a negative legal system, based on the "nonapplication of rules". This mechanism would create a "parallel regulatory system", namely the assumption of an alternative control mechanism to the ordinary, that legitimate any exceptionality, making it a "normal" tool. Instead, the legitimacy of the emergency, determined by the doctrine of necessity, would be an "ordinary parallel regime", whose exceptionality could dissolve in function of the fact of existing within a conventional regulatory system.

Therefore, it would be necessary to formalize the application of a state of emergency through the creation of a system of norms which individuals specific limits in addition to those generally described in the conventional legal system. Regardless of the branching model in emergency "restrictions" and "exceptions", it is inconceivable the idea of an imminent state of exception, as it would be legitimate to regard the intermittency of the rule of law as a legitimate assumption of the same. The application of emergency powers (coercive) would undermine the entire normative system as it would allow the establishment of a "previous regulatory extraordinary". If it is possible to depart a time, it is possible that this will happens again and, paradoxically, this may occur over time as the ordinary activities of a State.

So one might think that jus ad tumultum delegitimizes human rights in their own raison d'être, as attributable to a legal particularism risky for the authoritativeness and effectiveness of the international law of human rights. If there are human rights, it is paradoxical the establishment of an international conventional obligation and legitimating the "temporary cancellation" of the same, even if it is a way to resolve the issue of safeguarding the life of the nation. This emergency mechanism feeds the debate on the balance between 
Reason of State and the human rights, as it poses the question of the potential dichotomy between the nation-State and the rights of the community. In relation to this issue, in the light of doctrinal and jurisprudential debate, it may be desirable either the repeal of the standard suspension of human rights, or the enactment of regulations that prescribe the "limits to the exceptions" so specific and accurate. 
